\title{
Acid base disorders in hospitalized cattle
}

\section{Distúrbios ácido-base em bovinos hospitalizados}

\author{
Adriana Garzón-Audor'; Olimpo J. Oliver-Espinosa ${ }^{1}$ (D); Rubiela Castañeda-Salazar² \\ ${ }^{1}$ Universidad Nacional de Colombia, Facultad de Medicina Veterinaria y Zootecnia, Departamento de Salud Animal, Bogotá, Colombia \\ ${ }^{2}$ Pontificia Universidad Javeriana, Facultad de Ciencias, Departamento de Microbiología, Bogotá, Colombia
}

\begin{abstract}
The objectives of this retrospective study were to determine the main acid-base and electrolytes disorders in hospitalized cattle, using both Henderson-Hasselbalch and the physicochemical approach and to compare their diagnostic and therapeutic utility. A total of 31 medical records were reviewed of bovines admitted to the Large Animal Hospital at Universidad Nacional de Colombia, that met the inclusion criteria of the measurement of blood gases, blood electrolytes and plasma protein on admission before providing any treatment. Using the Henderson-Hasselbalch approach, acid base abnormalities were found in $83.3 \%$ of the patients, compared to $93.5 \%$ using the physicochemical approach. The principal acid-base disorders found were strong ion acidosis (61.29\%) and weak acid acidosis (38.7\%); strong ion gap (SIG) acidosis was found in $73.68 \%$ of cases showing strong ion acidosis. These results highlight the importance of the diagnosis of acid-base disorders in sick cattle for proper recognition of pathophysiological phenomena and its understanding to guide treatment decisions.
\end{abstract}

Keywords: Bovine. Physicochemical approach. Strong ion acidosis. Hyponatremia.

\section{RESUMO}

Os objetivos deste estudo retrospectivo foram determinar os principais distúrbios ácido-base e eletrolíticos em bovinos internados, utilizando a abordagem Henderson-Hasselbalch e a abordagem físico-química comparando a utilidade diagnóstica e terapêutica de tais procedimentos. Foram revisados 31 prontuários de bovinos admitidos no Hospital de Animais de Grande Porte da Universidad Nacional de Colombia, que preencheram os critérios de inclusão da medição de gases sanguíneos, eletrólitos sanguíneos e proteínas plasmáticas na admissão antes de fornecer qualquer tratamento. Com o emprego da abordagem de Henderson-Hasselbalch, as anormalidades da base ácida foram encontradas em 83,3\% dos pacientes, enquanto com a abordagem físico-química o valor obtido foi de $93,5 \%$. Os principais distúrbios ácido-base encontrados foram forte acidose iônica (61,29\%) e acidose ácida fraca (38,7\%). A acidose com Ion Gap Forte (SIG) foi encontrada em $73,68 \%$ dos casos com forte acidose iônica. Estes resultados destacam a importância do diagnóstico de distúrbios ácido-base em bovinos doentes para o reconhecimento adequado dos fenômenos fisiopatológicos e sua compreensão para orientar as decisões de tratamento.

Palavras-chave: Bovino. Abordagem físico-química. Forte diferença iônica. Hiponatremia.

Correspondence to:

Olimpo J. Oliver-Espinosa

Universidad Nacional Colombia, Facultad de Medicina

Veterinaria y Zootecnia, Departamento de Salud Animal

Carrera 45 \#26-85, Edificio Uriel Gutierrez

111321, Bogotá, Colombia

e-mail: ojolivere@unal.edu.co

Received: July 09, 2019

Approved: December 11, 2019
How to cite: Garzón-Audor A, Oliver-Espinosa OJ, Castañeda-Salazar R. Acid base disorders in hospitalized cattle. Braz J Vet Res Anim Sci. 2020;57(1):e159837. https:// doi.org/10.11606/issn.1678-4456.bjvras.2020.159837

\section{Introduction}

Acid base and electrolytic disorders are frequent findings in sick cattle (Constable et al., 2005; Gomez et al., 2013b; Roussel et al., 1998). There are two approaches to describe 
acid-base balance in mammals. One approach is the Henderson-Hasselbalch equation, which is a descriptive method that explains how plasma $\mathrm{pH}$ is influenced by the interaction of $\mathrm{CO}_{2}$ pressure $\left(p \mathrm{CO}_{2}\right)$, bicarbonate concentration $\left[\mathrm{HCO}_{3}^{-}\right]$, the equilibrium constant $\left(\mathrm{Pk}^{\prime}\right)$ and the solubility of $\mathrm{CO}_{2}$ in plasma $\left(\mathrm{SCO}_{2}\right)$ (Henderson, 1913). The other approach is the physicochemical method, which is a quantitative model that combines in polynomial equations the laws of electroneutrality, mass conservation and dissociation equilibrium of weak acids to determine the plasma $\mathrm{pH}$ based on three independent variables: strong ion difference (SID), $p \mathrm{CO}_{2}$ and total weak acid concentration (A) (Stewart, 1983).

Many studies using the physicochemical approach have been carried out in horses (Gomez et al., 2013a), pigs (Reinhold et al., 2010) and dogs (Sławuta et al., 2010); and acid base disorders in cattle have been widely described using the Henderson-Hasselbalch equation in gastrointestinal disorders in adult cattle (Braun et al., 1990; Ward et al., 1994), neonatal calf diarrhea (Naylor, 1989; Tennant et al., 1972), feeding changes in healthy animals (Oetzel et al., 1991) and normal newborn calves (Butler et al., 1971). However, fewer studies have been done using the physicochemical approach (Gomez et al., 2013b; Stämpfli \& Oliver, 2002; Stämpfli et al., 2012).

The objectives of this retrospective study were to determine the main acid-base and electrolytes disorders in hospitalized cattle by different diseases, using both Henderson-Hasselbalch and the physicochemical approach and to compare their diagnostic and therapeutic utility.

\section{Materials and Methods}

\section{Study population}

All the medical records $(\mathrm{n}=245)$ were reviewed of bovines admitted between January 2005 and July 2013 to the Large Animal Hospital at the Universidad Nacional de Colombia. Animals were included if the complete results of arterial or venous blood gases $\left(p \mathrm{O}_{2}(\mathrm{mmHg})\right.$ and $\left.p \mathrm{CO}_{2}(\mathrm{mmHg})\right)$, blood electrolytes $\left(\left[\mathrm{Na}^{+}\right],\left[\mathrm{K}^{+}\right]\right.$and $\left.\left[\mathrm{Cl}^{-}\right]\right)$and total plasma protein determination on admission before providing any treatment were registered on the medical records.

\section{Data collection}

Age, sex, breed, production purpose and diagnosis, as well as the first complete blood cell count, total plasma protein $(\mathrm{g} / \mathrm{L}$ ), liver function tests (aspartate aminotransferase $(\mathrm{U} / \mathrm{L})$ and gamma-glutamyl transferase $(\mathrm{U} / \mathrm{L}))$ or renal function tests (urea $(\mathrm{mmol} / \mathrm{L})$ and creatinine $(\mu \mathrm{mol} / \mathrm{L})$ ), were registered.

A blood sample from the coccygeal vein or artery using a heparinized syringe was taken the day of admission before any treatment was provided. $\mathrm{pH}$, blood gases $\left(\left(\mathrm{pO}_{2}(\mathrm{mmHg})\right.\right.$ and $\left.p \mathrm{CO}_{2}(\mathrm{mmHg})\right)$ and electrolytes $\left(\mathrm{Na}^{+}(\mathrm{mmol} / \mathrm{L})\right.$, $\mathrm{K}^{+}(\mathrm{mmol} / \mathrm{L})$ y Cl$\left.-(\mathrm{mmol} / \mathrm{L})\right)$ were measured. Blood samples that were taken between 2005 and February 2012 were sent to an external laboratory in Bogota, Colombia and analyzed using the Cobas ${ }^{\circledR}$ b 221 Blood gas system (Roche OMNI ${ }^{\circledR}$ S) for blood gases and $\mathrm{pH}$, and Vitros ${ }^{\circledR} 350$ Chemistry System (Ortho-Clinical Diagnostics-Johnson \& Johnson company ${ }^{\circledR}$ ) for electrolytes measurement. After May 2012, all blood samples were analyzed using the $\mathrm{EPOC}^{\circledR}$ Host Blood Analysis system (HH-0005-XU-00) for $\mathrm{pH}$ and blood gases and using an ion selective electrode (EPOC ${ }^{\circledR}$ BGE- Test Cards) for electrolytes measurement at the Clinical Pathology Laboratory, Faculty of Veterinary Medicine and Zootechnics, Universidad Nacional de Colombia, Bogota, Colombia.

The bicarbonate $\left[\mathrm{HCO}^{3-}\right](\mathrm{mmol} / \mathrm{L})$ (Constable, 2000), base excess $\left(\mathrm{BE}_{(\mathrm{ECF})}\right)(\mathrm{mmol} / \mathrm{L})$ (Constable, 2002; Gomez et al., 2013a) and anion GAP (mmol/L) (Constable et al., 1997; Constable, 2000) were calculated. For the physicochemical approach, the SID and $\mathrm{A}^{-}$variables were calculated using the Software by Stämpfli (2019) (Stewart Acid-Base Analysis ${ }^{\circledR}$ ) and the calculation of the SIG was performed according to the simplified strong ion model for the acid-base balance (Constable et al., 1997; Constable, 2000).

Acid base disorder definitions according to the Henderson-Hasselbalch and physicochemical approaches are presented in Tables 1 and 2.

Table 1 - Acid base disorders according to the Henderson-Hasselbalch approach, based on the normal values reported by Castañeda et al. (2002)

\begin{tabular}{lll}
\hline \multicolumn{1}{c}{ Acid base disorder } & & Arterial Blood \\
\hline Metabolic Acidosis & $\mathrm{BE}_{(\mathrm{ECF})}$ & $<-4.45 \mathrm{mmol} / \mathrm{L}$ \\
& {$\left[\mathrm{HCO}_{-}\right]$} & $<18.4 \mathrm{mmol} / \mathrm{L}$ \\
Metabolic Alkalosis & $\mathrm{BE}_{(\mathrm{ECF})}$ & $>6.63 \mathrm{mmol} / \mathrm{L}$ \\
& {$\left[\mathrm{HCO}_{-}\right]$} & $>21.66 \mathrm{mmol} / \mathrm{L}$ \\
Respiratory Acidosis & $p \mathrm{CO}_{2}$ & $>-5.93 \mathrm{mmol} / \mathrm{L}$ \\
Respiratory Alkalosis & $\mathrm{pCO}_{2}$ & $>30.1 \mathrm{mmol} / \mathrm{L}$ \\
\hline
\end{tabular}

$\mathrm{BE}_{(\mathrm{ECF})}=$ base excess of extracellular fluid; $[\mathrm{HCO} 3-]=$ bicarbonate concentration; $p \mathrm{CO}_{2}=$ partial pressure of carbon dioxide. 
Table 2 - Acid base disorders according to the physicochemical approach, based on the values reported by Stämpfli \& Oliver (2002)

\begin{tabular}{cc}
\hline Acid base disorder & Definition \\
\hline SID Acidosis & $\mathrm{SID}<38 \mathrm{mmol} / \mathrm{L}$ \\
SID Alkalosis & $\mathrm{SID}>44 \mathrm{mmol} / \mathrm{L}$ \\
A- Acidosis & $\mathrm{A}->13 \mathrm{mmol} / \mathrm{L}$ \\
A- Alkalosis & $\mathrm{A}-<12 \mathrm{mmol} / \mathrm{L}$ \\
SIG Acidosis & $\mathrm{SIG}<-3 \mathrm{mEq} / \mathrm{L}$ \\
\hline
\end{tabular}

$\mathrm{SID}=$ strong ion difference; $\mathrm{A}-=$ total weak acid concentration; $\mathrm{SIG}=$ strong ion gap.

Due to the fact that a retrospective study was conducted and all data were collected as part of routine diagnosis and treatment, but any intervention was carried out, no approval from the ethics committee was necessary.

\section{Statistical analysis}

Data were checked for normality using the Shapiro-Wilk test. Data that were normally distributed were expressed as mean \pm standard deviation and data with a non-normal distribution were expressed as median and range. Data were analyzed using Statgraphics ${ }^{\circledR 1}$ statistic software.

For the $\mathrm{pH}, \mathrm{pO}_{2}, \mathrm{pCO}_{2}, \mathrm{BE}_{(\mathrm{ECF})}$ and $\left[\mathrm{HCO}_{3}^{-}\right]$data, the values found by Castañeda et al. (2002) in cattle at 2.600 meters above sea level (the same altitude for animals included in the present study), were used as reference ranges, but using 2 standard deviations of the mean, assuming that data had a gaussian distribution; therefore, $95 \%$ of the distribution would include all data that were between 2 standard deviations of the mean.

The degree of agreement between both diagnostic approaches was determined using the Kappa statistic (Gordis, 2009). Receiver operating characteristic (ROC) curves analysis was used to evaluate the accuracy of both approaches as diagnostic tests for acid base disorders (Swets, 1988).

\section{Results}

Two hundred forty-five bovines were admitted to the Large Animal Hospital at Universidad Nacional de Colombia between January 2005 and July 2013 and 31 met the inclusion criteria. Twenty-four animals (77.41\%) were females and 7 (22.58\%) were males. The breeds in the study sample included 14 (45.16\%) that were Holstein, 7 (22.58\%) Simmental, 3 (9.67\%) Brahman, 2 (6.45\%) Normande, 1 (3.22\%) Angus, 1 (3.22\%) Brangus, 1 (3.22\%) Charolais, 1 (3.22\%) Brown Swiss, and in 1 (3.22\%), the type of breed was not available. The median age was 18 months, ranging from 1 day to 9 years of age.

Centurion $\mathrm{XVI}^{\circledR}$, Version 16.2.04. Statgraphics Technologies, Inc. The Plains, Virginia.
Two animals (6.45\%) had chronic suppurative pneumonia, 1 (3.22\%) enzootic pneumonia, 2 (6.45\%) aspiration pneumonia, 4 (12.9\%) neonatal septicemia, $4(12.9 \%)$ left abomasal displacement, 2 (6.45\%) intestinal accidents, 2 (6.45\%) hemoparasitism, 2 (6.45\%) neonatal calf diarrhea, 2 (6.45\%) bovine viral diarrhea, 2 (6.45\%) vagal indigestion, 1 (3.22\%) ruminal lactic acidosis, 1 (3.22\%) atresia coli, 1 (3.22\%) high mountain disease, 1 (3.22\%) toxic metritis, 1 (3.22\%) esophageal obstruction, 1 (3.22\%) urethral obstruction, 1 (3.22\%) pharyngeal paralysis, and 1 (3.22\%), salmonellosis. Eleven (35.48\%) animals were euthanatized, 9 (29\%) were discharged, 7 (22.58\%) died, and in 4 patients (12.9\%), the outcome was not registered.

Electrolytes derangements were diagnosed in 23 (74.2\%) of the animals and were classified as hyponatremia in 10 (32.25\%), hypernatremia in $2(6.45 \%)$, hypokalemia in $12(38.7 \%)$, hyperkalemia in $4(12.96 \%)$, hypochloremia in $13(41.93 \%)$ and hyperchloremia in 5 (16.12\%) animals. Two different electrolyte derangements were diagnosed in 10 animals and were classified as hypernatremia with hyperchloremia in $2(6.45 \%)$ and hyponatremia with hypochloremia in 8 (25.8\%) animals. (Table 3 )

Acid-base disturbances classified by the Henderson-Hasselbalch approach were diagnosed in $26(83.87 \%)$ patients, a single metabolic disorder was diagnosed in 11 patients. There were 2 cases $(18.18 \%)$ of metabolic acidosis based on $\mathrm{BE}_{\text {(ECF) }}(<-4.45$ (arterial); $<-2.07$ (venous) $(\mathrm{mmol} / \mathrm{L})), 5(45.45 \%)$ metabolic acidosis by $\mathrm{BE}_{(\mathrm{ECF})}$ and plasma $\left[\mathrm{HCO}_{3}^{-}\right](<18.24$ (arterial) $<21.66$ (venous) $\mathrm{mmol} / \mathrm{L})$, $4(36.36 \%)$ metabolic alkalosis by $\mathrm{BE}_{(\mathrm{ECF})}$ and plasma $\left[\mathrm{HCO}_{3}^{-}\right]$(>30.12 (arterial); $>30.34$ (venous) $\mathrm{mmol} / \mathrm{L}$ ). A single respiratory disorder was found in 8 patients $(30.76 \%)$, respiratory acidosis $\left(p \mathrm{CO}_{2}>43.85\right.$ (arterial); $>50.98$ (venous) $\mathrm{mmHg}$ ) and respiratory alkalosis $\left(\mathrm{CO}_{2}<31.65\right.$ (arterial); $<37.14$ (venous) $\mathrm{mmHg}$ ) were found in 4 and 4 of the patients, respectively. Mixed metabolic acid-base abnormalities were diagnosed in 7 patients (26.92\%): 4 cases of metabolic acidosis by $\mathrm{BE}_{(\mathrm{ECF})}$ and plasma $\left[\mathrm{HCO}_{3}^{-}\right]$with respiratory acidosis; 1 case of metabolic alkalosis by $\mathrm{BE}_{(\mathrm{ECF})}$ and plasma $\left[\mathrm{HCO}_{3}^{-}\right]$with respiratory acidosis, and 2 cases of metabolic alkalosis by $\mathrm{BE}_{(\mathrm{ECF})}$ and plasma $\left[\mathrm{HCO}_{3}^{-}\right.$] with respiratory alkalosis. Furthermore, anion GAP acidosis $(<14 \mathrm{mEq} / \mathrm{L})$ was found in 10 patients with metabolic acidosis. Acid base disorders according to the Henderson-Hasselbalch approach are presented in Figure 1.

Acid-base disturbances classified by the physicochemical approach were diagnosed in 29 (93.54\%) patients (Figure 2), a single disorder was diagnosed in 9 patients. There were $4(44.44 \%)$ cases of weak acid acidosis (A- $>13 \mathrm{mmol} / \mathrm{L}$ ), 2 (22.22\%) strong ion alkalosis ( $\mathrm{SID}>44 \mathrm{mmol} / \mathrm{L}), 2(22.22 \%)$ strong ion acidosis (SID $<38 \mathrm{mmol} / \mathrm{L}$ ), and 1 (11.11\%) weak 
Table 3 - Acid base variables from 31 bovine patients (Reference values reported by Castañeda et al., 2002; Ontario Veterinary College, 1992; Stämpfli \& Oliver, 2002)

\begin{tabular}{|c|c|c|}
\hline Parameter & Values & Ref. Value \\
\hline $\mathbf{p H}_{\text {(Arterial) }}$ & $7.38 \pm 0.15(6.99-7.59)$ & 7.38-7.46 \\
\hline $\mathrm{pH}_{\text {(Venous) }}$ & & 7.33-7.42 \\
\hline$p \mathrm{CO}_{2 \text { (Arterial) }}(\mathrm{mmHg})$ & $39.82 \pm 12.29(19.9-71.9)$ & $31.65-43.85$ \\
\hline $\mathrm{pCO}_{2 \text { (Venous) }}(\mathrm{mmHg})$ & & $37.14-50.98$ \\
\hline $\mathrm{HCO}_{3}^{-}$(Arterial) $(\mathrm{mmol} / \mathrm{L})$ & $24.66 \pm 9.37(5.6-48.2)$ & $18.24-30.12$ \\
\hline $\mathrm{HCO}_{3}^{-}{ }_{\text {(Venous) }}(\mathrm{mmol} / \mathrm{L})$ & & $21.66-30.34$ \\
\hline $\mathrm{BE}_{\text {(ECF) (Arterial) }}(\mathrm{mmol} / \mathrm{L})$ & $-0.39 \pm 11.27(-25.11-29.35)$ & $-4.45-6.63$ \\
\hline $\mathrm{BE}_{\text {(ECF) (Venous) }}(\mathrm{mmol} / \mathrm{L})$ & & $-2.07-5.93$ \\
\hline $\mathrm{Na}^{+}(\mathrm{mmol} / \mathrm{L})$ & $135.35 \pm 12.72(104-170)$ & $132-152$ \\
\hline $\mathrm{K}^{+}(\mathrm{mmol} / \mathrm{L})$ & $4.04 \pm 1.11(2-6.92)$ & $3.9-5.2$ \\
\hline $\mathrm{Cl}^{-}(\mathrm{mmol} / \mathrm{L})$ & $96.71 \pm 15.47(62-129)$ & $97-111$ \\
\hline SID (mEq/L) & $37.49 \pm 10.25(26.7-62.5)$ & $8-44$ \\
\hline$A-(m E q / L)$ & $12.83 \pm 2.83(8.1-20.8)$ & $12-13$ \\
\hline AG (mEq/L) & $18.01 \pm 8.66(-1.05-40.96)$ & $14-20$ \\
\hline SIG (mEq/L) & $-5.17 \pm 8.24(-20.16-14.90)$ & $-3+3$ \\
\hline $\mathrm{TP}(\mathrm{g} / \mathrm{L})$ & $70(46-122)$ & $67-75$ \\
\hline
\end{tabular}

$p \mathrm{CO}_{2}=$ partial pressure of carbon dioxide; [HCO3- $]=$ bicarbonate concentration; $\mathrm{BE}_{(\mathrm{ECF})}=$ base excess of extracellular fluid; Na ${ }^{+}=$sodium; $\mathrm{K}^{+}=$potassium; $\mathrm{Cl}^{-}=$chloride; $\mathrm{SID}=$ strong ion difference; A- =total weak acid concentration; $\mathrm{AG}=$ anion gap; $\mathrm{SIG}=$ strong ion gap; TP $=$ total plasma proteins.

A

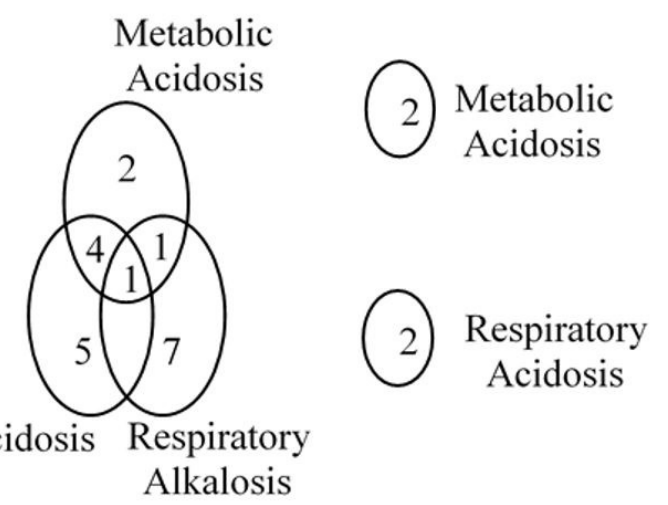

B

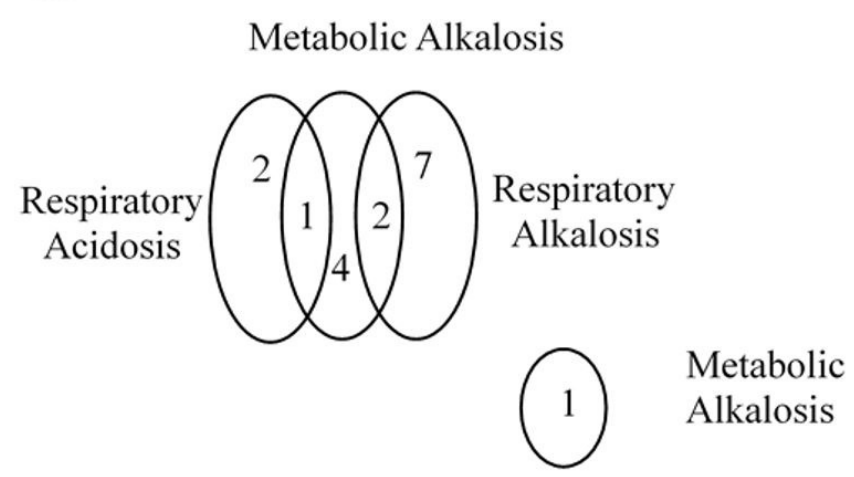

Figure 1 -Acid-base disorders according to the Henderson-Hasselbalch approach. (A) Metabolic acidosis, respiratory alkalosis and anion gap (AG) acidosis; (B) Metabolic alkalosis, respiratory alkalosis and acidosis.
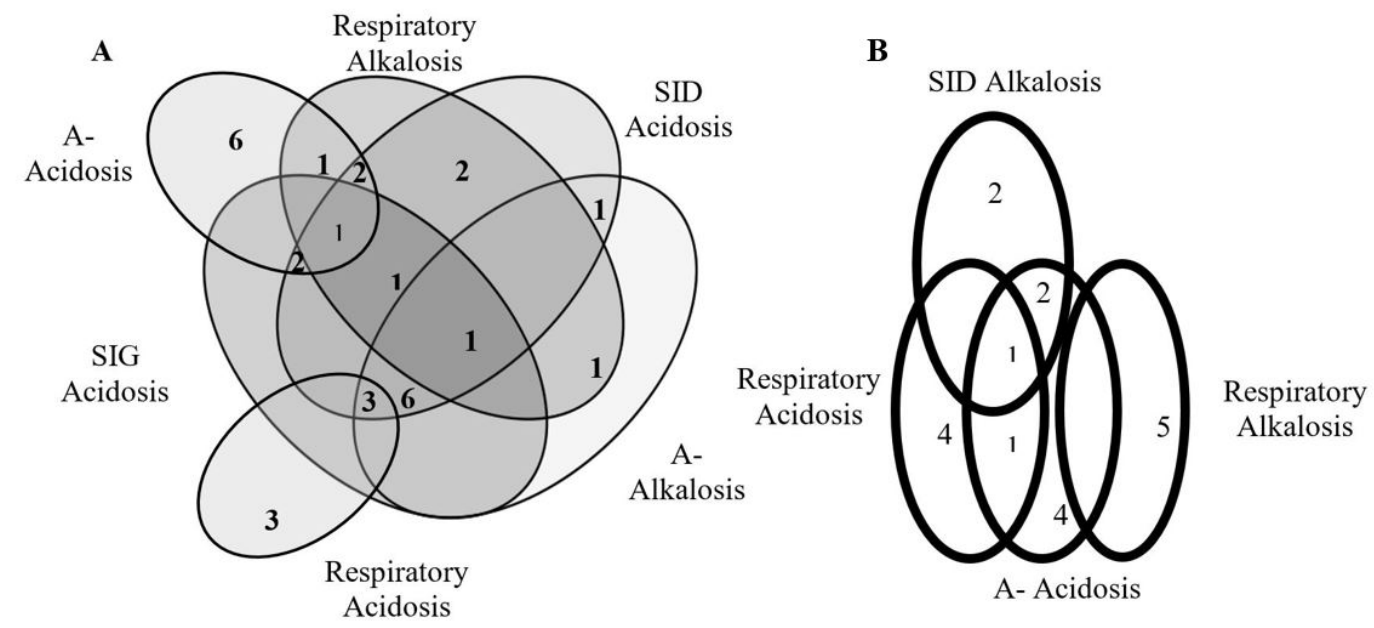

Figure 2 - Acid-base disorders according to the physicochemical approach. (A) Strong ion (SID) acidosis, SID acidosis, Weak acid (A-) acidosis and alkalosis, respiratory acidosis and alkalosis; (B) SID alkalosis, A- acidosis, respiratory acidosis, respiratory alkalosis and strong ion gap (SIG) acidosis. 

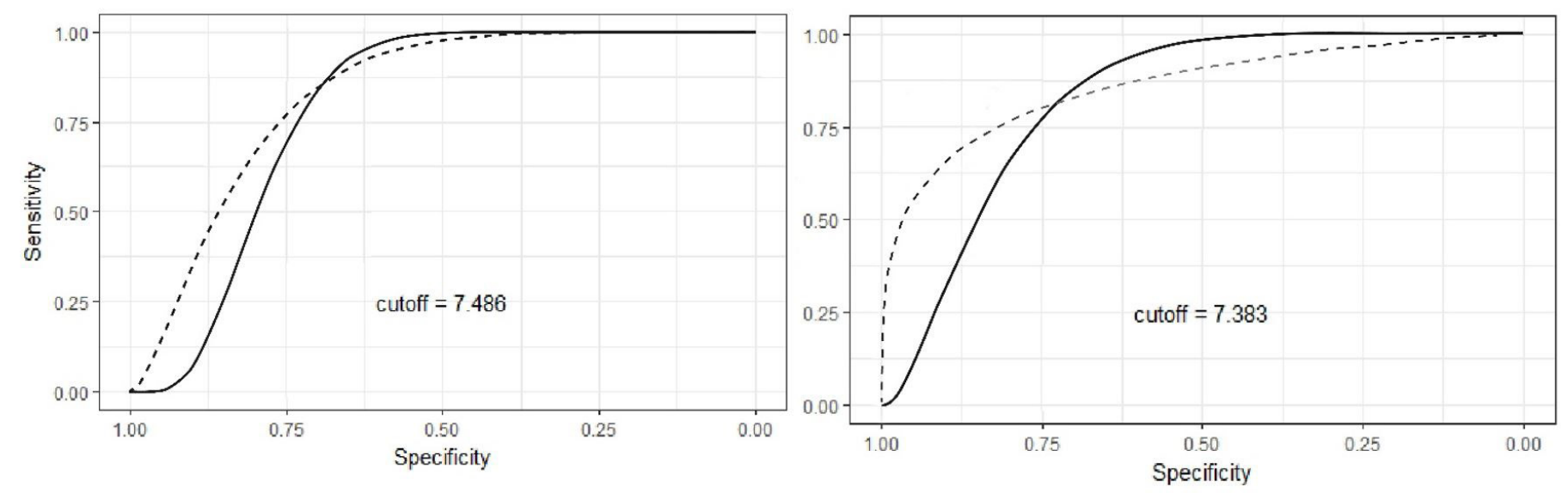

Figure 3 - Receiver operating characteristic curves (ROC) analysis for physicochemical and Henderson-Hasselbalch approach for detecting acid-base disorders A. ROC analysis for alkalosis, AUC for physicochemical approach: 0.838; AUC for Henderson-Hasselbalch approach: 0.75. B. ROC analysis for acidosis, AUC for physicochemical approach: 0.875, AUC for Henderson-Hasselbalch approach: 0.848 (dash line: physicochemical approach; solid line: Henderson-Hasselbalch approach).

acid acidosis (A- $<12 \mathrm{mmol} / \mathrm{L}$ ). Concomitant disorders were diagnosed in $20(64.51 \%)$ patients: 4 (20\%) had SID alkalosis and weak acid acidosis, 10 (50\%) had SID acidosis and weak acid alkalosis, and $6(30 \%)$ had both SID and weak acid acidosis. Altogether, strong ion acidosis was diagnosed in 19 patients, weak acid acidosis in 12, strong ion alkalosis in 5 and weak acid alkalosis in 12. Also, 10 (52.63\%) of the SID acidosis cases had decreased SIG (SIG <-3 mEq/L), 5 (26.31\%) were hyponatremic, $2(10.52 \%)$ hyponatremic and had decreased SIG, and 2 (10.52\%) had decreased SIG and were hyperchloremic. All cases of SID alkalosis were also hypochloremic. (Figure 2)

The Kappa statistic showed a $38.1 \%$ agreement between the Henderson-Hasselbalch and physicochemical approaches.

ROC analysis showed an area under the curve of 0.838 and 0.75 for the diagnosis of alkalosis and 0.875 and 0.848 for the diagnosis of acidosis, according to the physicochemical and Henderson-Hasselbalch approaches, respectively (Figure 3 ).

\section{Discussion}

The most common disorder found, following the Henderson-Hasselbalch approach, was metabolic acidosis by $\mathrm{BE}_{(\mathrm{ECF})}$ and also by plasma [HCO3-]. In patients younger than 3 months, the main disorder was metabolic acidosis by $\mathrm{BE}_{(\mathrm{ECF})}$ and/or by plasma [HCO3-]; meanwhile, in patients older than 3 months, the most common disorder was the metabolic alkalosis. This difference may be the result of physiological changes related to rumen development during the first months of life (Drackley, 2008) and also, as a consequence of metabolic acidosis occasioned by the presentation of neonatal diarrhea, which is the most important disease in neonatal calves (Barrington et al., 2002). Conversely, the most common disorder in older patients may be associated with abomasal disturbances involving the sequestration of chloride in the fore-stomach (Ward et al., 1994).

Metabolic acidosis has been described as a frequent acid base alteration in calves (Tennant et al., 1972; Naylor, 1987) and has been attributed in diarrheic calves, mainly to bicarbonate ion losses and in dehydrated patients, to decreased renal excretion of hydrogen ions, besides plasma lactic acid accumulation, secondary to anaerobic glycolysis caused by poor tissue hypoperfusion (Kasari \& Naylor, 1986; Naylor, 1987; Tennant et al., 1972) or D-lactic acid gain due to bacterial fermentation (Ewaschuk et al., 2005; Omole et al., 2001). In adult cattle, metabolic alkalosis has been described related to gastrointestinal disorders as right abomasal displacement, abomasal volvulus, small intestinal obstruction and vagal indigestion (Braun et al., 1990; Roussel et al., 1998), as well as cattle treated with oral magnesium hydroxide (Kasari et al., 1990; Ogilvie et al., 1983). Due to the limited number of cases, a statistical correlation between etiologies and acid base disorders was not feasible. However, a hypochloremic metabolic alkalosis was identified in patients diagnosed with abomasal ulcer, vagal indigestion, small intestine intussusception and intestinal accident, in agreement with the expected clinical pathology findings of these etiologies in which abomasal reflux occurs and chloride and hydrogen ions are sequestered into the forestomach compartments known as functional pyloric stenosis (Braun et al., 1990; Ward et al., 1994).

AG acidosis was found in 10 patients. All calves $<3$ months diagnosed with metabolic acidosis by $\mathrm{BE}_{(\mathrm{ECF})}$ or plasma [HCO3-], had also an increased anion GAP, probably due to increased plasma either D- or L-lactic acid (Omole et al., 2001). Metabolic acidosis in calves used to be attributed to the increased AG, secondary to L-hyperlactatemia (Naylor, 1987), although, in most recent studies, this association has 
not been found (Kasari \& Naylor, 1984). Meanwhile, blood D-lactate (which is produced by bacterial fermentation in the gastrointestinal tract) has been related to metabolic acidosis in calves without dehydration (Ewaschuk et al., 2004; Lorenz, 2009) and only a moderate association between anion GAP and L-lactate in adult cattle has been described, limiting the usefulness to predict blood concentration of L-lactate in sick cattle (Constable et al., 1997).

Despite the clinical relevance of the Henderson-Hasselbalch approach, the accuracy of the model is affected in sick animals as a consequence of alterations in $\mathrm{pH}$, plasma protein and sodium concentrations (Constable et al., 1997).

According to the physicochemical approach, the most common acid base disorder was strong ion acidosis, as well as weak acid alkalosis and strong ion acidosis concurrent with weak acid alkalosis. SID acidosis may be occasioned by the decrease in $\left[\mathrm{Na}^{+}\right]$, increase in $[\mathrm{Cl}]$ or accumulation of metabolically produced organic acids (lactate, acetoacetate or ß-hydroxybutyrate) (Whitehair et al., 1995). Hyponatremia has been widely studied in diarrheic calves, as a consequence of increased water losses in the gastrointestinal tract along with electrolytes (mainly sodium and potassium) (Roussel et al., 1998; Tennant et al., 1972) and for reduced milk intake (Berchtold, 2009). Moreover, hyponatremia has been an important finding in acidotic sick calves with or without diarrhea (Constable et al., 2005; Gomez et al. , 2013b), in agreement with the findings of the present study.

Hyperchloremic acidosis has been ascribed to the therapeutic use of $0.9 \% \mathrm{NaCl}$ solutions (Stämpfli \& Constable, 2003), and has been experimentally induced in calves to resemble metabolic acidosis secondary to diarrhea or ruminal acidosis (Gentile et al., 2008). Nonetheless, in this study, there were two cases of hyperchloremic acidosis along with increased SIG; therefore, acidosis could not be ascribed exclusively to the increased $\left[\mathrm{Cl}^{-}\right]$in those patients.

In a study carried out in 264 calves with neonatal diarrhea, strong ion gap (SIG) acidosis was the principal disorder and was diagnosed in $80 \%$ of the calves (Gomez et al., 2013b). Strong ion acidosis with increased SIG, has been attributed to the increased [lactate], both L and D isomers, as a consequence of hypoperfusion and hypovolemia secondary to dehydration, which results on an increased anaerobic glycolysis and organic acids (L-lactate) (Tennant et al., 1972), and bacterial production of D-Lactate in gastrointestinal tract, due to carbohydrate malabsorption (Ewaschuk et al., 2004; Omole et al., 2001).

Total plasma proteins are the main component of A- therefore, their concentration affect, in an independent way, the acid base balance. Hence, hypoproteinemia and hyperproteinemia caused alkalemia and acidemia, respectively (Stämpfli \& Constable, 2003). In a retrospective study of 231 diarrheic calves, ruminal drinkers and septic diarrheic calves, weak acid acidosis was found due to the increased total plasma protein (Constable et al., 2005). Changes in plasma protein in sick animals may be related to the hydration status (Constable et al., 1998), but it may occur as consequence of other factors. As such, weak acid alkalosis may be due to decreased synthesis (hepatic failure, malnutrition, malabsorption), increased loss (urinary losses with nephropathy or enteropathy with protein loss) and increased capillary permeability (Wilkes, 1998). In this study, the cause of hypoproteinemia could not be identified, although, in three patients it could be caused by hepatic failure reflected by an increased in liver enzymes (AST and GGT).

The ROC analysis showed that the accuracy detecting acid-base disorders is higher in the physicochemical than in the Henderson-Hasselbalch approach. This approach allowed detecting more abnormalities, which may affect the selected treatment, and probably enhances the odds of a more positive outcome of these patients. The kappa statistic showed a fair agreement between the two approaches, due to the higher sensitivity of the physicochemical approach, especially in the diagnosis of alkalosis. Therefore, acid base disturbances following the Henderson-Hasselbalch approach may be misdiagnosed and the prognosis of those patients may be aggravated.

In conclusion, the physicochemical approach allowed detection of more acid base disturbances in hospitalized cattle than the Henderson-Hasselbalch approach. These results indicate the need to determine accurately the acid-base disorders in hospitalized cattle for their adequate treatment.

The limitations of this retrospective study are the limited number of clinical cases, which precluded eliciting statistical correlations between the etiology and the acid-base disorder, and use of two different blood gas analyzers, which may affect the accuracy of the blood gas measures.

\section{Conflict of Interest}

The authors declare no potential conflicts of interest with respect to the work presented in this report. The authors are responsible for the content and the writing of the paper.

\section{Ethics Statement}

This study was a retrospective study of records of patients already treated at Large Animal Hospital at Universidad Nacional de Colombia that did not involve direct animal use.

\section{Acknowledgements}

The authors wish to thank Dr. Henry Staempfli for creating the Software (Stewart Acid-Base Analysis ${ }^{\circledR}$ ) that is of open use. 


\section{References}

Barrington GM, Gay JM, Evermann JF. Biosecurity for neonatal gastrointestinal diseases. Vet Clin North Am Food Anim Pract. 2002;18(1):7-34. http://dx.doi.org/10.1016/S0749-0720(02)000051. PMid:12064170.

Berchtold J. Treatment of calf diarrhea: intravenous fluid therapy. Vet Clin North Am Food Anim Pract. 2009;25(1):73-99, vi. http://dx.doi.org/10.1016/j.cvfa.2008.10.001. PMid:19174284.

Braun U, Steiner A, Kaegi B. Clinical, haematological and biochemical findings and the results of treatment in cattle with acute functional pyloric stenosis. Vet Rec. 1990;126(5):107-10. PMid:2309403.

Butler DG, Willoughby RA, Mcsherry BJ. Studies on diarrhea in neonatal calves. 3. Acid-base and serum electrolyte values in normal calves from birth to ten days of age. Can J Comp Med. 1971;35(1):36-9. PMid:4251412.

Castañeda R, Moreno C, Oliver O, Donado P. Acid-base balance in bovine anaplasmosis. In Proceedings of the XXII World Buiatrics Congress; 2002; Hannover, Germany. Hannover: World Association for Buiatrics; 2002. p. 23-4.

Constable PD, Stämpfli HR, Navetat H, Berchtold J, Schelcher F. Use of a quantitative strong ion approach to determine the mechanism for acid-base abnormalities in sick calves with or without diarrhea. J Vet Intern Med. 2005;19(4):581-9. PMid:16095178.

Constable PD, Streeter RN, Koenig GJ, Perkins NR, Gohar $\mathrm{HM}$, Morin DE. Determinants and utility of the anion gap in predicting hyperlactatemia in cattle. J Vet Intern Med. 1997;11(2):71-9. http://dx.doi.org/10.1111/j.1939-1676.1997. tb00076.x. PMid:9127293.

Constable PD, Walker PG, Morin DE, Foreman JH. 1998: Clinical and laboratory assessment of hydration status of neonatal calves with diarrhea. J Am Vet Med Assoc. 1998;212(7):991-6. PMid:9540870.

Constable PD. Calculation of variables describing plasma nonvolatile weak acids for use in the strong ion approach to acid-base balance in cattle. Am J Vet Res. 2002;63(4):482-90. http://dx.doi.org/10.2460/ajvr.2002.63.482. PMid:11939307.

Constable PD. Clinical assessment of acid-base status: comparison of the Henderson-Hasselbalch and strong ion approaches. Vet Clin Pathol.2000;29(4):115-28. http://dx.doi.org/10.1111/j.1939165X.2000.tb00241.x. PMid:12070822.
Drackley JK. Calf nutrition from birth to breeding. Vet Clin North Am Food Anim Pract. 2008;24(1):55-86. http://dx.doi. org/10.1016/j.cvfa.2008.01.001. PMid:18299032.

Ewaschuk JB, Naylor JM, Palmer R, Whiting SJ, Zello GA. D-lactate production and excretion in diarrheic calves. J Vet Intern Med. 2004;18(5):744-7.http://dx.doi.org/10.1111/j.1939-1676.2004. tb02615.x. PMid:15515594.

Ewaschuk JB, Naylor JM, Zello GA. D-lactate in human and ruminant metabolism. J Nutr. 2005;135(7):1619-25. http:// dx.doi.org/10.1093/jn/135.7.1619. PMid:15987839.

Gentile A, Lorenz I, Sconza S, Klee W. Experimentally induced systemic hyperchloremic acidosis in calves. J Vet Intern Med. 2008;22(1):190-5.http://dx.doi.org/10.1111/j.1939-1676.2008.0028.x. PMid:18289309.

Gomez DE, Arroyo LG, Stämpfli HR, Cruz LE, Oliver OJ. Physicochemical interpretation of acid-base abnormalities in 54 adult horses with acute severe colitis and diarrhea. J Vet Intern Med. 2013a;27(3):548-53. http://dx.doi.org/10.1111/ jvim.12071. PMid:23551698.

Gomez DE, Lofstedt J, Stämpfli HR, Wichtel M, Muirhead T, Mcclure JT. Contribution of unmeasured anions to acid-base disorders and its association with altered demeanor in 264 calves with neonatal diarrhea. JVet Intern Med. 2013b;27(6):1604-12. http://dx.doi.org/10.1111/jvim.12193. PMid:24107246.

Gordis L. Epidemiology. 4th ed. United States: Elsevier; 2009. $446 \mathrm{p}$.

Henderson LJ. The regulation of neutrality in the animal body. Science. 1913;37(950):389-95. http://dx.doi.org/10.1126/ science.37.950.389. PMid:17795147.

Kasari TR, Naylor JM. Further studies on the clinical features and clinicopathological findings of a syndrome of metabolic acidosis with minimal dehydration in neonatal calves. Can J Vet Res. 1986;50(4):502-8. PMid:3024795.

Kasari TR, Naylor JM. Metabolic acidosis without clinical signs of dehydration in young calves. The Canadian Veterinary. 1984;25(10):394-9. PMid:17422463.

Kasari TR, Woodbury AH, Morcom-Kasari E. Adverse effect of orally administered magnesium hydroxide on serum magnesium concentration and systemic acid-base balance in adult cattle. J Am Vet Med Assoc. 1990;196(5):735-42. PMid:2307611. 
LorenzI. D-Lactic acidosis in calves. Vet J.2009;179(2):197-203. http://dx.doi.org/10.1016/j.tvjl.2007.08.028. PMid:17933565.

Naylor JM. A retrospective study of the relationship between clinical signs and severity of acidosis in diarrheic calves. Can Vet J. 1989;30(7):577-80. PMid:17423372.

Naylor JM. Severity and nature of acidosis in diarrheic calves over and under one week of age. Can Vet J. 1987;28(4):168-73. PMid:17422754.

Oetzel GR, Fettman MJ, Hamar DW, Olson JD. Screening of anionic salts for palatability, effects on acid-base status, and urinary calcium excretion in dairy cows. J Dairy Sci. 1991;74(3):96571. http://dx.doi.org/10.3168/jds.S0022-0302(91)78245-3. PMid:2071720.

Ogilvie TH, Butler DG, Gartley CJ, Dohoo IR. Magnesium oxide induced metabolic alkalosis in cattle. Can J Comp Med. 1983;47(2):108-11. PMid:6883181.

Omole OO, Nappert G, Naylor JM, Zello GA. Both L- and D-lactate contribute to metabolic acidosis in diarrheic calves. J Nutr. 2001;131(8):2128-31. http://dx.doi.org/10.1093/ jn/131.8.2128. PMid:11481406.

Ontario Veterinary College. Veterinary Teaching Hospital. Veterinary Hospital undergraduate manual. Ontario: Ontario Veterinary College, Veterinary Teaching Hospital; 1992.

Reinhold P, Hartmann H, Constable PD. Characterisation of acid-base abnormalities in pigs experimentally infected with Chlamydia suis. Vet J. 2010;184(2):212-8. http://dx.doi. org/10.1016/j.tvjl.2009.02.005. PMid:19286403.

Roussel AJ, Cohen ND, Holland PS, Taliaoferro L, Green R, Benson P, Navarre CB, Hooper RN. Alterations in acid-base balance and serum electrolyte concentrations in cattle: 632 cases (1984-1994). J Am Vet Med Assoc. 1998;212(11):176975. PMid:9621887.

Sławuta P, Nicpoń J, Skrzypczak P. Contemporary approach to acid-base balance and its disorders in dogs and cats. Pol. Pol J Vet Sci. 2010;13(3):561-7. PMid:21033575.

Stämpfli H, Oliver O. How to use the routine serum biochemical profile to understand and interpret acid- base disorders in the ruminant? In Proceedings of the XXII World Buiatrics Congress; 2002; Hannover, Germany. Hannover: World Association for Buiatrics; 2002. p. 23-4.

Stämpfli HR, Constable PD. Experimental determination of net protein charge and $\mathrm{A}$ (tot) and $\mathrm{K}$ (a) of nonvolatile buffers in human plasma. J Appl Physiol. 2003;95(2):620-30. http:// dx.doi.org/10.1152/japplphysiol.00100.2003. PMid:12665532.

Stämpfli HR, Oliver O, Pringle JK. Clinical evaluation of an oral electrolyte solution formulated based on Strong Ion Difference (SID) and using propionate as the organic anion in the treatment of neonatal diarrheic calves with strong ion acidosis. Open J Vet Med. 2012;2(1):34-9. http://dx.doi.org/10.4236/ojvm.2012.21006.

Stämpfli HR. Stewart Acid-Base Analysis ${ }^{\circledR}$ [Internet]. Ontario: University of Guelph; 2019 [cited 2019 July 9]. Available from: http://www.uoguelph.ca/ pjf/1.4.html

Stewart PA. Modern quantitative acid-base chemistry. Can J Physiol Pharmacol. 1983;61(12):1444-61. http://dx.doi. org/10.1139/y83-207. PMid:6423247.

Swets JA. Measuring the accuracy of diagnostic systems. Science. 1988;240(4857):1285-93. http://dx.doi.org/10.1126/ science.3287615. PMid:3287615.

Tennant B, HarroldD, Reina-Guerra M. Physiologic and metabolic factors in the pathogenesis of neonatal enteric infections in calves. J Am Vet Med Assoc. 1972;161(9):993-1007. PMid:4563254.

Ward JL, Smith DF, FubiniSL, Deuel-Aromando DM. Evaluation of abomasal outflow diversion as an experimental model of hypochloremic, hypokalemic metabolic alkalosis in lactating cows. Can J Vet Res. 1994;58(1):13-9. PMid:8143247.

Whitehair KJ, Haskins SC, Whitehair JG, Pascoe PJ. Clinical applications of quantitative acid-base chemistry. J Vet Intern Med. 1995;9(1):1-11.http://dx.doi.org/10.1111/j.1939-1676.1995. tb03265.x. PMid:7891356.

Wilkes P. Hypoproteinemia, strong-ion difference, and acid-base status in critically ill patients. J Appl Physiol. 1998;84(5):1740-8. http://dx.doi.org/10.1152/jappl.1998.84.5.1740. PMid:9572825.

Financial Support: None 